\title{
Sustainable Water Supply Strategy for Bangalore - A Model for Emerging Cities in India
}

\section{Ammanaghatta Rudrappa Shivakumar}

KSCST, Indian Institute of Science, Bangalore, India

\section{Email address:}

rainmanskumar@gmail.com

\section{To cite this article:}

Ammanaghatta Rudrappa Shivakumar. Sustainable Water Supply Strategy for Bangalore - A Model for Emerging Cities in India. International Journal of Science, Technology and Society. Vol. 6, No. 1, 2018, pp. 6-12. doi: 10.11648/j.ijsts.20180601.12

Received: August 23, 2017; Accepted: November 15, 2017; Published: December 14, 2017

\begin{abstract}
Water supply for the city of Bangalore in India is always short against the total demand. Surface water is inadequate to meet the demand and the city has to depend on groundwater. Due to rapid urbanization, infiltration of rainwater into the subsoil has decreased drastically and recharging of groundwater has diminished. This scenario requires an alternative source to bridge the gap between demand and supply. Rainwater, which is easily available and is the purest form of water, would be an immediate source to augment the existing water supply by "catching water wherever it falls". Recycling or reuse of treated water is another source for at least secondary purposes. Karnataka State Council for Science and Technology (KSCST) is actively participating in the socially relevant, environment friendly water conservation measures and has been providing cost effective solutions since its inception 1975. Rainwater Harvesting (RWH) Cell at KSCST is established to study the needs of the people and provide sustainable and simple solutions through innovation and implementation pertinent to Rainwater Harvesting and Ground water recharge. Since November 2005 RWH Cell has provided technical support for planning rainwater harvesting systems in over 300 institutions (Public and private sector, Multinationals and Educational Institutions) in Karnataka and other states of India. Several thousand visitors have personally visited KSCST and availed the benefit and technical knowledge on RWH, water conservation and ground water recharge. RWH cell established at KSCST is providing policy support to the Government departments for water conservation and rainwater harvesting programmes in Karnataka and other states in India. RWH App is developed with the support of UNESCO by KSCST for web and Mobile users. Blog "Rain Man Speaks from Bengaluru" is in the web since April 1st 2014 and has published 81 posts. Quiz and Debate programs are organised to build awareness on rainwater harvesting and water conservation measures among students and faculty of schools and colleges. Case Study 1: 'Sourabha' Ecofriendly home of Bangalore in India is on a plot area of 2400 Sq. ft. This house is entirely dependent on harvested rainwater for all its need including drinking since 1994. Case Study 2: The strategy for sustainable water supply plan for a city like Bangalore should have the combination of conventional river water supply augmented by the 'New Water' supply sources - a. Rainwater harvesting, b. Ground water recharge with sustainable withdrawal and c. Reuse of waste water through treatment.
\end{abstract}

Keywords: Rainwater Harvesting, Sustainable Water Supply, Water Supply Strategy to Bangalore, Recharging of Groundwater, Sourabha Ecofriendly Home, Rainwater Harvesting Cell, RWH App, RWH Advisor

\section{Introduction}

Water supply for the city of Bangalore in India is always short against the total demand. Surface water is inadequate to meet the demand and the city has to depend on groundwater. Due to rapid urbanization, infiltration of rainwater into the subsoil has decreased drastically and recharging of groundwater has diminished. This scenario requires an alternative source to bridge the gap between demand and supply. Rainwater, which is easily available and is the purest form of water, would be an immediate source to augment the existing water supply by "catching water wherever it falls" [1]. Recycling or reuse of treated water is another source for at least secondary purposes.

Rainwater Harvesting (Figure 1) has emerged as a viable alternative to traditional perennial sources of water in urban 
areas facing water shortage and flooding during monsoons.

The estimated population of Bangalore Bruhath Bangalore Maha Nagara Palikey's (BBMP's) 198 wards as per the 2011 census is 84.74 lakhs (8.474 million), up from 45.92 lakh in 2001. The population of men and women is 44 lakh and 40 lakh respectively. Since the population is below 1 crore (10 million), Bangalore remains a B class city [2].

The population density in Bangalore has risen $47 \%$ in the past decade as job opportunities and economic growth have attracted people to Bangalore. The number of people living per square kilometer in the city has increased to 4,378 in 2011 from 2,985 in 2001.

Seven neighboring city municipal councils, a municipal town and 110 villages were merged into Bangalore in 2007.

Bangalore is now expanded to $800 \mathrm{sq} \mathrm{km}$ in its area. Bangalore Water Supply and Sewerage Board (BWSSB) is planning to cover the BBMP area of $800 \mathrm{sq} \mathrm{km}$. BWSSB has 8, 94,393 (Nov 2016) connections for delivery of water which encompasses domestic, institutional, commercial Government and others.

Realized the importance of harvesting rainwater and as a first step through BWSSB, RWH has been made mandatory for most of the properties in Bangalore since Nov 2009.

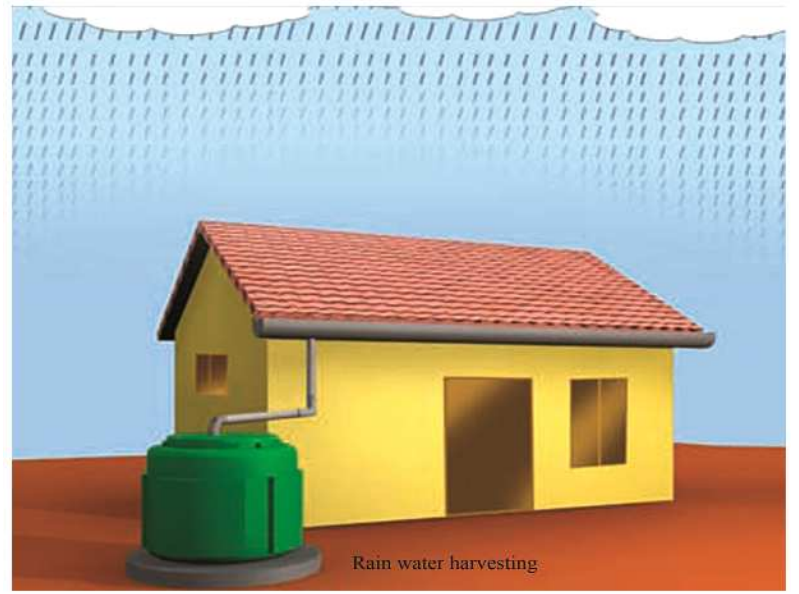

Figure 1. Rainwater Harvesting from building roof.

\section{Methodology}

Karnataka State Council for Science and Technology (KSCST) is actively participating in the socially relevant, environment friendly water conservation measures and has been providing cost effective solutions since its inception 1975. Rainwater Harvesting (RWH) Cell at KSCST is established to study the needs of the people and provide sustainable and simple solutions through innovation and implementation pertinent to Rainwater Harvesting and Ground water recharge. Since November 2005 RWH Cell has provided technical support for planning rainwater harvesting systems in over 300 institutions (Public and private sector, Multinationals and Educational Institutions) in Karnataka and other states of India. Several thousand visitors have personally visited KSCST and availed the benefit and technical knowledge on RWH, water conservation and ground water recharge [3].

RWH cell established at KSCST is providing policy support to the Government departments for water conservation and rainwater harvesting programmes in Karnataka and other states in India (Figure 2). The guidelines established by RWH Cell are instrumental in pursuing State Government to amend several acts and issue guidelines for mandatory installation of RWH structures in all the government buildings, public parks, roads and open spaces. Bangalore Water Supply and Sewerage Board (BWSSB) has collaborated with RWH Cell of KSCST and brought in the legislation to compulsorily install RWH system in certain category of properties in Bengaluru.

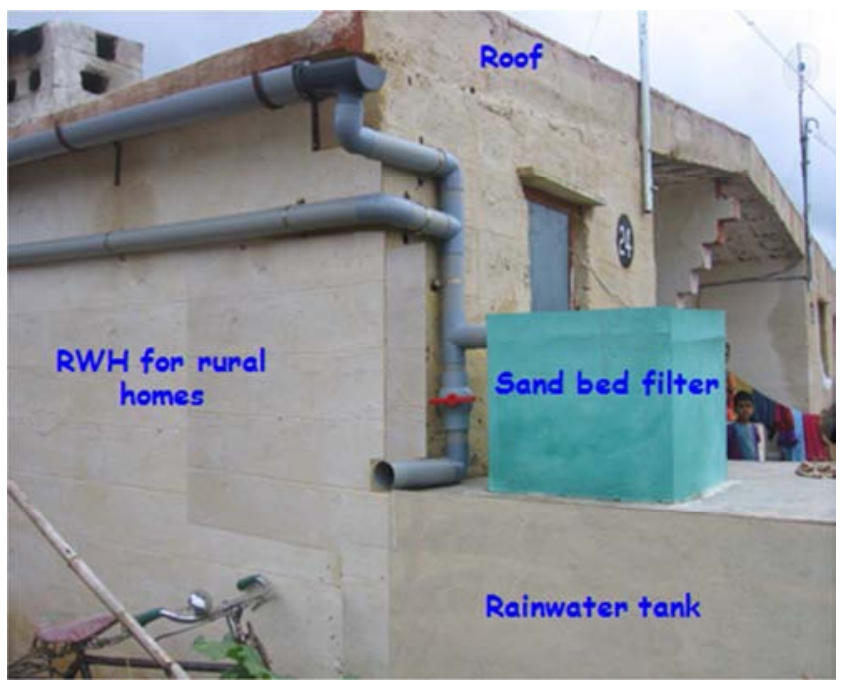

Figure 2. RWH in village home.

\subsection{Training Programme}

Skill development programme to train Architects, Engineers and Plumbing contractors for hands on training and rainwater harvesting project planning are being conducted every month. Since inception 74 training programmes are conducted till date and around 1,800 trained personals are offering their services. The list of these trained personals with contact details is available in the web link http://www.kscst.iisc.ernet.in/rwh_files/rwh_contractors.html

\subsection{Web and Mobile Phone App}

RWH App is developed with the support of UNESCO by KSCST for web and Mobile users. Software Application "Do it Yourself RWH Tool - RWH Advisor" was launch on the occasion of World Water Day celebrations at Water Festival 2016 on 22.03.2016 at Bharat Nivas, Auroville, Pondicherry by UNESCO representatives. http://rwh-advisor.info

\subsection{Blog and Social Media}

Blog "Rain Man Speaks from Bengaluru" is in the web since April 1st 2014 and has published 81 posts. The reach as of February 2017 is over 52,000 and in over 20 countries. Blog is reposted on Facebook, Tweeter, and Google+ etc. 
http://rainmanspeaks.blogspot.in

\subsection{Outreach Activities}

Quiz and Debate programs are organised to build awareness on rainwater harvesting and water conservation measures among students and faculty of schools and colleges. Over sixty five Quiz and Debate programs were conducted in Schools and colleges between October, 2013 and February, 2017 at sixty five Private and Government High Schools and Colleges in Bengaluru. This program has benefited 15,000 students and around 300 school teachers who participated in Quiz. The programmes were organised with the cooperation of over 150 volunteers from Nisarga Mahila Samaja.

Several lectures and presentations are being delivered to promote rainwater harvesting by the Council across the state, in addition to news paper articles and television programs.

Technical support and interaction is being provided through, email, web site information, facebook, blog and Do It Yourself RWH web and android based app supported by UNESCO http://rwh-advisor.info

\section{Help Desk and Support Network - Rainwater Harvesting, Ground Water Recharge and Water Management Programme for Bangalore City}

Government of Karnataka realized the importance of harvesting rainwater and as a first step through BWSSB, RWH has been made mandatory for most of the properties in Bangalore effective from November 2009 [3].

1. KSCST with the support of BWSSB has established RWH Helpdesk at KSCST in Indian Institute of Science campus and also at Rainwater Harvesting theme park in Jayanagar Bangalore. This 1.5 acre park on 40th Cross in Jayanagar V Block, demonstrates all techniques of harvesting rainwater. It has 26 working models on rainwater harvesting, ground water recharge and water conservation. The Theme park established by KSCST is the first of its kind in the country, to address frequently asked questions on rainwater harvesting, water collecting systems, filtration and storage systems and groundwater recharge methods.

2. The helpdesk primarily aims at training the stake holders such as architects, engineers, contractors, plumbers, masons, etc within Bangalore city through several Training Programmes. Awareness Camps are arranged to bring in awareness among the general public regarding Rainwater Harvesting. Information on technical details of RWH and ground water recharge are being provided at RWH helpdesk for those who visit KSCST or contact through telephone, web and email.

3. Skill development programme to train Architects, Engineers and Plumbing contractors for hands on training and rainwater harvesting project planning are being conducted every month. Since inception 74 training programmes are conducted till date and around 1,800 trained personals are offering their services.

4. People seeking assistance regarding Rainwater Harvesting (RWH) visit RWH helpdesk at KSCST regularly. Around 20,100 students and teachers from 331 schools and 2,850 students and lecturers from 109 colleges in and around Bengaluru visited Helpdesk at Sir M Visvesvaraiah Rainwater Harvesting Theme Park, Jayanagar. Over 33,000 people have visited RWH helpdesks at KSCST and RWH Themepark till date. They are given practical demonstration with the working models and RWH system at KSCST office by the helpdesk engineers. Feedback from the visitors to the Helpdesk are being collected regularly and analysed for improving the effectiveness of the programme.

5. Phone-in queries regarding RWH are being attended appropriately through the helpline numbers: 080 23341652, 080 23348848, 08023348849 and 080 26653666 at Jayanagar. RWH Theme Park. Around 3000 queries are answered by helpdesk engineers. Various types of questions are convincingly answered. Citizens are also helped to get the contacts of respective plumbers and contractors in their area who execute RWH works. Emails and web enquiries are answered regularly.

6. Print and electronic media (News papers, TV, Radio etc.) presented several articles in concern with RWH and RWH Helpdesk activities.

7. RWH helpdesk at KSCST has emerged as one stop solution and an effort of the Council to conserve water in the city of Bangalore. Rainwater Harvesting is one of the prioritized projects of KSCST and an important measure to mitigate water scarcity and augment existing water supply.

\section{Case Study 1 - Sourabha Ecofriendly Home of Bangalore in India [4]}

Sourabha (Figure 3) is located in southwestern part of Bangalore (Vijayanagar). Plot area is 2400 Sq.ft. (40ft. X $60 \mathrm{ft}$.). House constructed during 1995. This house is entirely dependent on rainwater for all its need since 1994 (including construction).

Rainwater falling inside the plot is being channeled to three applications.

i. Roof top rainwater harvesting

ii. Roof top rainwater channeled to recharge ground water

iii. Percolation in garden area to recharge ground water.

Majority of the rainwater falling on the roof $(85 \%)$ is channeled to the northern side of the house and is allowed flow in to a tank of 4500 lts. capacity built on the ground floor roof. PopUp filter along with a stabilization tank specially designed will filter the roof water before storing. This water is used during the rainy season. The over flow of this tank is allowed to rundown through rainwater pipe on the 
wall to an underground sump-1 of 25,000 lt capacity built under the portico at the entrance of the house. In the event of these two tanks getting full, the rainwater is diverted to percolate into the ground through a system of percolation tanks / infiltration gallery (4 recycled plastic drums interconnected and buried underground with their bottom cut open) to recharge ground water.

The remaining portion of the roof water $(15 \%)$ is allowed to rundown through rainwater pipe on the wall and a PopUp filter installed at the ground level filters suspended and floating material. Relatively cleaner water after filtration flows to an underground sump-2 of 10,000 lt Capacity built inside the car park (garage). Sump-1 and sump-2 together with 35,000 lt capacity are interconnected and the stored rainwater water is used during the non rainy days when the roof top tank water is not available.

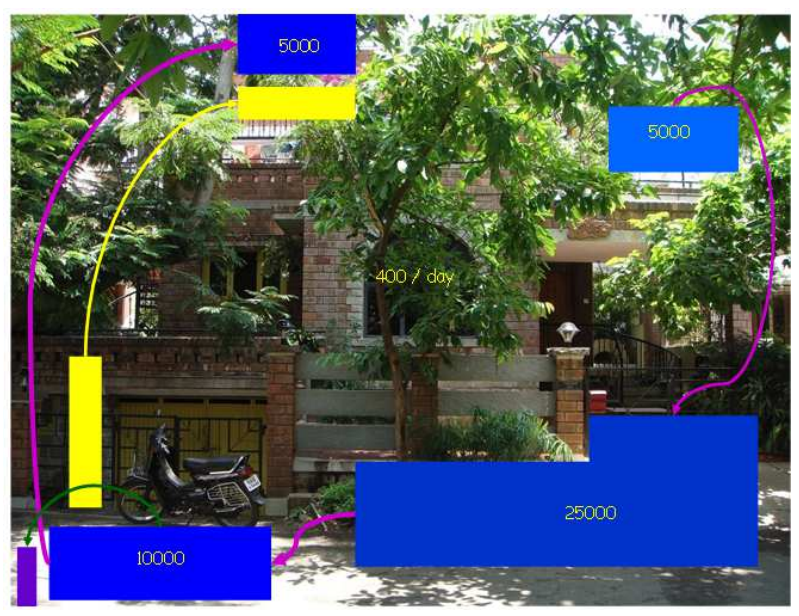

Figure 3. Rainwater harvesting in Sourabha.

Rainwater falling in the open area or the garden area around the house is allowed to percolate then and there in to the ground to recharge ground water.

In this manner not a drop of rainwater falling in the plot is allowed to flow out.

Bangalore receives around $1000 \mathrm{~mm}$ of rainfall in a year. Which translates in to around 2, 23,000 lts per year cumulatively in a plot of $60 \mathrm{ft}$. X $40 \mathrm{ft}$. Bangalore has an advantage of having nearly 70 rainy days spread throughout the year.

There is no Corporation or BWSSB water connection to this house. Clean and safe water is available 24 hours 365 days a year and the quality of water is also periodically tested and found to be good.

'Sourabha' house has inbuilt simple mechanisms to effectively harness all the rainwater falling in the plot and channel the same for different purposes. Even before constructing the house, rainwater harvesting was the answer for the water requirement. The house was constructed by using the harvested rainwater. Since 1995 the entire house needs including potable water is met out of rainwater. As a family of four, water required per month is around 15,000 lts.

A family require around $400 \mathrm{lt}$ per day for all the needs except for toilet flushing and part of gardening. The need of toilet flushing is met by recirculation of used water from laundry washing machine. Used water from washing machine is stored in an underground tank and is pumped up to a tank on the roof with vetiver grass. The aerated washing machine discharge water is then used for toilet flushing. Wash water from kitchen sink is diverted for gardening.

During days with more than 100 days of continues no rainy days which is very rare in Bangalore, water drawn from a shallow tube well, which gets recharged from rainwater, meets the requirement. Ground water table in and around the plot before the rainwater harvesting was as deep as $200 \mathrm{ft}$. (Sourabha is located on the top most position of a ridge). Within one year of ground water recharge, water is available at around $40 \mathrm{ft}$. In Sourabha the amount of water used is far less than the amount of rainwater harvested and ground water recharged. Consequent to this, a social cause to recharge the ever-dwindling ground water is also attempted.

There is no recurring cost involved except for the electricity used for pumping up water. The electricity consumption in Sourabha is around $80 \mathrm{kWh}$ (units) per month, which includes water pumping also. Low electricity consumption in the house is due to several energy conservation methods and renewable energy techniques adopted in the house.

Green building standards achieved for living in Sourabha:

i. Water requirement of $400 \mathrm{lt}$ per day and only harvested rainwater used all through the year

ii. Electricity consumption of only $80 \mathrm{kWh}$ per month

iii. LPG cylinder of $14 \mathrm{~kg}$ lasts for around 90 days

iv. Only $2 \mathrm{~kg}$ of dry rejects as waste goes out of the house per week. All organic waste converted and used as manure through vermicompost.

\section{Case Study 2 - Sustainable Water Supply Plan for Bangalore}

Water supply to Bangalore need to be provided in tune with both urban population growth and industrial expanse. It is logical to consider new sources of water i.e., recycled / reprocessed water as well as harvesting of rainwater which will make both economic and ecological sense.

Comprehensive Plan with Rainwater Harvesting as the New Decentralized Source

Meteorological data reveals that the rainfall in Bangalore is increasing and this is a recent phenomenon. 100 years of rain fall statistics puts average annual rainfall at $929 \mathrm{~mm}$ and 57 rainy days in Bangalore. Bangalore city has the expanse of 800 sq. km. urban spread with Two Million properties (both domestic and non-domestic). The population of Bangalore is 8.5 Million and the water supply at the tap end (excluding losses) is 685 MLD (total supply 1350 MLD Unaccounted for water 665 MLD) Figure 4 [5]. Considering the average roof area available for roof top rainwater harvesting per property at 110 sq.m., the roof top rainwater potential in Bangalore is 81,752 Million Litres (at $80 \%$ collection efficiency). 


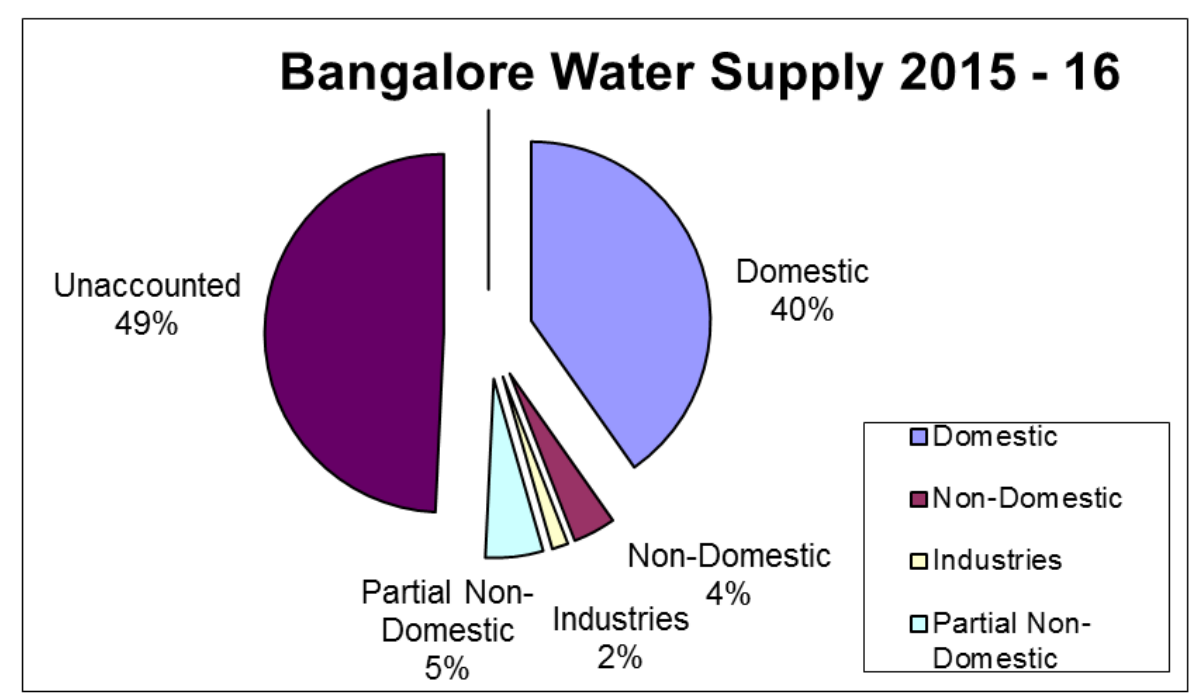

Figure 4. Bangalore water supply- sector vise.

The precipitation in the open space of Bangalore can generate water to the tune of 492,370 Million Litres. Considering only $20 \%$ of this is recharged to ground water through rainwater harvesting initiatives 98,474 Million Litres will be available for sustainable withdrawal from ground water.

Cauvery water supply at the tap end in Bangalore is 250,057 ML (685 MLD) Roof top rainwater Harvesting can provide
2,04,380 ML, Ground water available through RWH will be $1,85,800 \mathrm{ML}$ and the facilities of waste water treatment plants can provide $1,89,800 \mathrm{ML}$ Totaling to $3,07,048 \mathrm{ML}$ or 841 MLD. The "New Water" available at consumer end from the three sources (RWH, Ground water and Waste water treatment plants) will be 509 MLD which is almost equal to the current water supply at the tap end Figure 5.

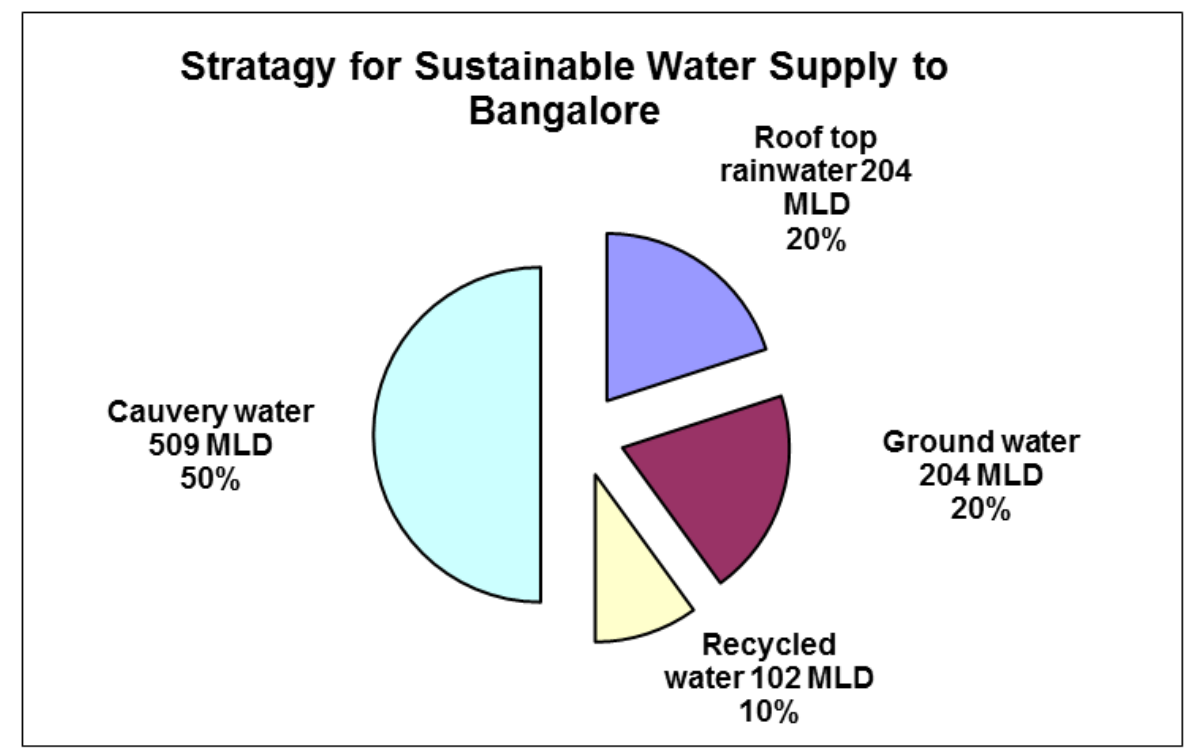

Figure 5. Sustainable water supply plan for Bangalore.

Table 1. [5] [6]. Bangalore water supply and availability data.

\begin{tabular}{lll}
\hline Bangalore Data & Units & Value \\
\hline Urban Population (2011) & Million & 84.6 \\
City Roads (length) & km & 1,500 \\
Number of Properties & No. & $20,00,000$ \\
Area & sq km & 800 \\
Water supply 2015 & MLD & 1350 \\
Water Demand 2015 & MLD & 1850 \\
Short fall & MLD & 500 \\
Projection & & 1470 \\
Supply 2017 & MLD & \\
\hline
\end{tabular}




\begin{tabular}{|c|c|c|}
\hline Bangalore Data & Units & Value \\
\hline Demand 2021 & MLD & 2100 \\
\hline Short fall & MLD & 630 \\
\hline Cauvery water supply 2011 & TMC & 12.25 \\
\hline Cauvery water allotment & TMC & 19 \\
\hline Rainfall in Bangalore (100 years average) & $\mathrm{mm}$ & 929 \\
\hline Rainy days in Bangalore per year & No. & 57 \\
\hline Number of properties in Bangalore - BMP & No. & $20,00,000$ \\
\hline Average roof area of a property (estimate) & sq $\mathrm{m}$ & 110 \\
\hline Sump size in each property - proposed & lt & 5,000 \\
\hline \multirow{2}{*}{ Total water storage capacity in Bangalore properties } & lt & $100000,00,000$ \\
\hline & ML & 10,000 \\
\hline Urban population & No. & $845,70,000$ \\
\hline \multirow{2}{*}{ BBMP area } & $\mathrm{sq} \mathrm{km}$ & 800 \\
\hline & $\mathrm{sq} \mathrm{m}$ & $8000,00,000$ \\
\hline \multirow{2}{*}{ Total water supply per day BWSSB } & MLD & 1,350 \\
\hline & lt & $13500,00,000$ \\
\hline BWSSB transmission losses & $\%$ & 49 \\
\hline \multirow{2}{*}{ Actual water supply per day } & MLD & 685 \\
\hline & lt & $6850,87,878$ \\
\hline Recycled water available from BWSSB (Tertiary Treatment) & MLD & 520 \\
\hline Water requirement days & No. & 365 \\
\hline Water unit & ML & $10,00,000$ \\
\hline Rainwater potential in BMP area (annual) & ML & $7,43,200$ \\
\hline Water requirement of Bangalore - BMP area (annual) & ML & $4,92,750$ \\
\hline Number of families in Bangalore & No. & $169,14,000$ \\
\hline \multirow{2}{*}{ Roof Top Rainwater Yield (Annual) } & lt & $2043800,00,000$ \\
\hline & ML & $2,04,380$ \\
\hline Roof Top Rainwater available @ 80\% effic (Annual) & ML & $1,63,504$ \\
\hline Roof Top Rainwater available - days & No. & 239 \\
\hline \multirow{2}{*}{ Rainwater Yield from BMP open area (Annual) } & lt & $3901800,00,000$ \\
\hline & ML & $3,90,180$ \\
\hline Open Area Rainwater available - days & No. & 570 \\
\hline Total number of days rainwater available per year & No. & 808 \\
\hline Availability of Rainwater in Bangalore to meet the demand & Months & 26.9 \\
\hline Detergents used in each house per month & $\mathrm{kg}$ & 5 \\
\hline \multirow{2}{*}{ Detergents used in Bangalore per day } & $\mathrm{kg}$ & $28,19,000$ \\
\hline & tone & 2,819 \\
\hline Detergents used in Bangalore per day & truck loads & 282 \\
\hline Per capita water availability BWSSB & lt & 16 \\
\hline Per capita water availability BWSSB actual & lt & 8 \\
\hline
\end{tabular}

Table 2. Sustainable water supply plan for Bangalore.

\begin{tabular}{lll}
\hline Strategy for Sustainable Water Supply to Bangalore & $\mathbf{1 0 0}$ & $\mathbf{1 , 0 1 8}$ \\
\hline & $\mathbf{\%}$ & MLD \\
\hline Roof top rainwater & 20 & 204 \\
Ground water & 20 & 204 \\
Recycled water & 10 & 102 \\
Cauvery water & 50 & 509 \\
\hline
\end{tabular}

Table 3. Sustainable water management plan for Bangalore.

\begin{tabular}{lll}
\hline Water Requirement - How to meet? & ML / Yr & MLD \\
\hline Total & $2,50,057$ & 685 \\
Roof top rainwater available & $2,04,380$ & 560 \\
Roof top rainwater required & 74,281 & 204 \\
Water required from ground water recharge & 74,281 & 204 \\
Potential for ground water recharge and withdraw & $1,85,800$ & 509 \\
Recycled water for secondary water use required & 37,140 & 102 \\
Recycled water for secondary water use available & $1,89,800$ & 520 \\
Cauvery water required & $1,85,702$ & 509 \\
Cauvery water available & $4,92,750$ & 1,350 \\
Excess Cauvery water available for new areas in BBMP & $3,07,048$ & 841 \\
Year & & $2015-2016$ \\
Water supplied & ML & $2,50,057$ \\
Water received & ML & $4,92,750$ \\
Unaccounted & ML & $2,42,693$ \\
\hline
\end{tabular}




\begin{tabular}{lll}
\hline Water Requirement - How to meet? & ML / Yr & MLD \\
\hline Accounted & $\%$ & 51 \\
Unaccounted & $\%$ & 49 \\
Number of Bore wells in Bangalore (conservative estimate) & No. & $4,00,000$ \\
Cost of each borewell & Rs. & $1,00,000$ \\
Total investment on bore wells in Bangalore & Million Rs. & 40,000 \\
Investment on water storage sump & Rs. per lt. & 5 \\
Total investment on water storage sumps in Bangalore & Million Rs. \\
MLD - Million Liter per Day & & 50,000 \\
ML - Million Liter & & \\
lt - Liter & & \\
\hline
\end{tabular}

\section{Conclusion}

The strategy for sustainable water supply plan for a city like Bangalore should have the combination of conventional river water supply augmented by the 'New Water' supply sources (a. Rainwater harvesting, b. Ground water recharge with sustainable withdrawal and c. Reuse of waste water through treatment).

\section{Abbreviations}

Rainwater Harvesting (RWH)

Karnataka State Council for Science and Technology (KSCST)

Bangalore Bruhath Bangalore Maha Nagara Palikey's (BBMP's)

Bangalore Water Supply and Sewerage Board (BWSSB)

Kilometre - km

Million Liter - ML

Million Liter per Day - MLD

Thousand Million Cubic Feet - TMC ft

Mille Metre - mm

\section{References}

[1] 'Amruthavarshini' A Guide for Rainwater Harvesting, by A. R. Shivakumar.

[2] Task Force for Recovery of Public Land and Its Protection Bangalore June 2011, By V. Balasubramanian IAS (Ret.).

[3] Karnataka State Council for Science and Technology web site, http://www.kscst.iisc.ernet.in/rwh.html

[4] Rain Dance on the Roof Top - Water Energy Environment for a sustainable living, By A. R. Shivakumar.

[5] Bangalore Water Supply and Sewerage Board (BWSSB), Annual report 2014-15.

[6] Bangalore Water Problems of the Fast Growing City of India, Editor Subhajyoti Das 2011.

[7] Groundwater Development and Rainwater Harvesting in Grater Bangalore, By R. H. Sawkar.

[8] Bangalore Water Supply and Sewerage Board (BWSSB), Annual report 2015-16.

[9] Technology, Environment, and Sustainable Development, By Dr. Arcot Ramachandran and Dr. M. Ramaiah.

[10] Bruhath Bangalore Mahanagara Palike websit information, http://bbmp.gov.in/home 